\title{
Archaeological Testing In An Area South of Olmos Dam, San Antonio, Texas
}

Cristi A. Assad

Follow this and additional works at: https://scholarworks.sfasu.edu/ita

Part of the American Material Culture Commons, Archaeological Anthropology Commons, Environmental Studies Commons, Other American Studies Commons, Other Arts and Humanities Commons, Other History of Art, Architecture, and Archaeology Commons, and the United States History Commons

Tell us how this article helped you.

This Article is brought to you for free and open access by the Center for Regional Heritage Research at SFA ScholarWorks. It has been accepted for inclusion in Index of Texas Archaeology: Open Access Gray Literature from the Lone Star State by an authorized editor of SFA ScholarWorks. For more information, please contact cdsscholarworks@sfasu.edu. 


\section{Archaeological Testing In An Area South of Olmos Dam, San Antonio, Texas}

Creative Commons License

(c) $)$ (i) @

This work is licensed under a Creative Commons Attribution-NonCommercial 4.0 International License 


\section{Archaeological Testing In An Area South of Olmos Dam, San Antonio, Texas}

CRISTI A. ASSAD

Center for Archaeological Research

The University of Texas at San Antonio Archaeological Survey Report, No. 54

1978 
ARCHAEOLOGICAL TESTING IN AN AREA

SOUTH OF OLMOS DAM, SAN ANTONIO, TEXAS

Cristi A. Assad

Center for Archaeological Research The University of Texas at San Antonio Archaeological Survey Report, No. 54

1978 
List of Figures and Tables................. i i

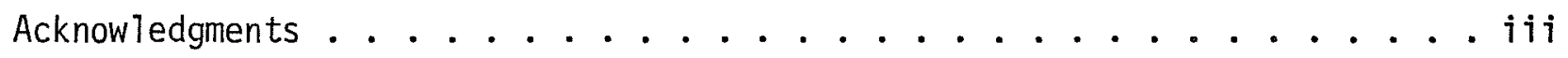
Introduction. ..................... 1 Generat Background . . . . . . . . . . . . 1

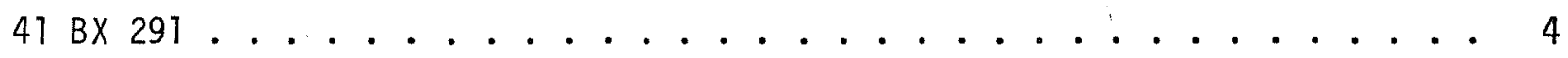
Previous Research................... . 4 Site Description................. 4 Investigation Activities ............. 4 Lithic Artifacts . . . . . . . . . . . . . . . 11 Anglo-European Historic Disturbance. . . . . . . . . . . 11 Land Snail Remains................. . . 13 Summary and Recommendations ................. 13 References Cited. . . . . . . . . . . . . . . . 14 
Figure

1. Location of $41 \mathrm{BX} 291 \ldots \ldots 2$

2. Site Map of $41 \mathrm{BX} 291 \ldots . . \ldots 3$

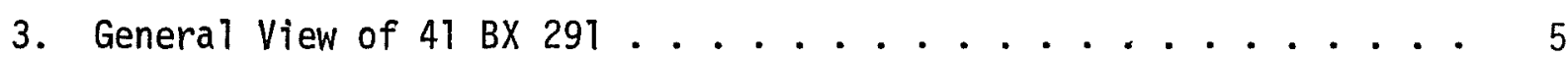

4. Artifacts from $41 \mathrm{BX} 291$ and the Shovel Tests ........ 5

5. Profiles of Units 1 and 2 ................. 7

6. Profiles of Shovel Tests ST-B, ST-C and ST-F ........ 8

Table

1. Artifacts Recovered from 41 BX 291 Units 1 and 2 ...... 9

2. Artifacts from the Shovel Tests ............. 10

3. Land Snail Distribution at 41 BX 291 and Vicinity . . . . . . 12 


\section{ACKNOWLEDGMENTS}

The work accomplished for this project was greatly facilitated by several people. Mr. C. D. Orchard, Anne A. Fox and Carolyn Furman were very helpful with suggestions and background information of the study area. Thanks are also extended to Susanna Katz of Incarnate Word College for her information and help.

I am very grateful to Dr. Thomas R. Hester, Director of the Center for Archaeological Research (CAR), The University of Texas at San Antonio (UTSA), and Jack D. Eaton, Assistant Director, for their guidance, suggestions and editing of this report. Augustine Frkuska (of CAR) was very helpful in preparing some of the report materials. 


\section{INTRODUCTION}

During November of 1977, five days of archaeological testing were carried out by personnel from the Center for Archaeological Research, The University of Texas at San Antonio, directly south of $01 \mathrm{mos}$ Dam, San Antonio, Texas (see Fig. 1). The testing was done under the supervision of Dr. Thomas R. Hester, Director, and Jack D. Eaton, Assistant Director, and was performed under the terms of a contract between CAR and the San Antonio River Authority. The project conforms to the provisions outlined in the E.D.A. Special Terms and Conditions (III 3a), Grant Number 08-19-01911. Antiquities Permit \#161 was obtained from the Texas Historical Commission before field work commenced.

This phase of testing was recommended by Brown (1977), who conducted the pre7 iminary survey in the area prior to planned modifications to 01 mos Dam. A prehistoric archaeological site, $41 \mathrm{BX} 291$, is located immediately south of the dam. The installation of a security fence at the property line between Incarnate Word College and the City of San Antonio was recommended by Brown (1977) to protect $41 \mathrm{BX} 291$. The site was designated a State Landmark, along with four other sites in the 01mos Basin (Brown 1977).

The main objective of this testing was to define and evaluate what effect the construction of a new fence would have on 41 BX 291 and any other archaeologically significant resources which may be located along the proposed fence line. The location of the security fence is the same as that of the existing fence.

The extent of the testing of $41 \mathrm{BX} 291$ was limited to a small portion of the site which is on the City of San Antonio's property. The major part of the site is on land owned by Incarnate Word College (see Fig. 2). Two excavation units at $41 \mathrm{BX} 291$, in addition to shovel testing along the rest of the fence line, were deemed satisfactory in providing the information needed to make the necessary evaluations and recommendations regarding potential impact on the site.

The field work was supervised by Cristi Assad who was assisted by Augustine Frkuska and Edwin S. Harris. All notes, maps and materials collected are on file at the Center.

\section{General Background}

01 mos Dam was built after a destructive flood in 1921 inundated parts of San Antonio, Texas. The structure has a northeast/southwest axis and is 1,941 feet in length (Orchard and Campbe11 1954). 01mos Dam is roughly one-half mile north of where 01mos Creek, an intermittent stream, joins the San Antonio River near its head at Incarnate Word College.

The soils of this portion of the 01 mos Basin are of the Trinity type. Trinity soil is found on flood plains of small streams which are usually flooded at least once a year. The soil texture is a clay loam to gravelly clay (Taylor, Hailey and Richmond 1966).

A great deal of alteration has occurred in the vicinity of the 01 mos Basin. Natural and modern forces, such as repeated flooding and the construction of the 01 mos Dam, have probably caused many changes to 41 BX 291. A11 or part of the 
This page has been

redacted because it

contains restricted

information. 
This page has been

redacted because it

contains restricted

information. 
site had been under cultivation in the past, and it is very probable that some of the site had been bulldozed during construction of 0lmos Dam (Susanna Katz, personal communication). Evidence of a sewer pipe is present along the eastern side of the site (see Fig. 2).

The vegetation of the area between the dam and the present fence line has been altered in modern times, with the possible exception of two large oak trees on the far western side of the creek. A variety of brushy trees is growing along the fence line including hackberry, sumac, elm, persimmon and mesquite. Thick grasses cover most of the space between the fence and the dam (Fig. 3 ).

\section{BX 291}

One of the objectives of this field work was to determine, if possible, the boundaries of 41 BX 291 as it extends north of the Incarnate Word College property. This action was necessary in order to make recommendations for construction of the proposed security fence designed to protect $41 \mathrm{BX} 291$.

\section{Previous Research}

The major portion of 41 BX 291 is located on property owned by Incarnate Word College. Archaeological testing of the site was conducted in 1977 by Susanna Katz, Instructor of Anthropology, Incarnate Word College, and Dr. Paul Katz, Research Associate, Incarnate Word College and the Center for Archaeological Research (UTSA). The analys is of that work is in progress at this time. A brief inspection of a few diagnostic artifacts from that testing indicated that the Late Prehistoric and Late Archaic chronologic periods are represented in the upper $30 \mathrm{~cm}$ of the site. More detailed information about $41 \mathrm{BX} 291$ should be available upon the publication of the Katzes' investigations.

Orchard and Campbell (1954) briefly discuss the immediate vicinity near $41 \mathrm{BX}$ 291, while Fox (1975) and Brown (1977) conducted surveys and limited testing at or near the site itself.

\section{Site Description}

41 BX 291 is an occupation site that is semicircular in plan and covers an area of approximately $1800 \mathrm{~m}^{2}$ (Fox 1975). The site is located on a low rise in the center of the $07 m o s$ Creek flood plain at 680 feet in elevation as recorded on USGS topographic maps. 01mos Creek, in its present location, lies about $100 \mathrm{~m}$ to the east of the site. Testing indicated that the boundaries of $41 \mathrm{BX} 291$ extend roughly $23 \mathrm{~m}$ north of the property fence and that it is $50 \mathrm{~m}$ in width. The cultural deposit of the site overlies a buff white calcareous soil/bedrock. The deposit at the center of the slight mound is $60 \mathrm{~cm}$ deep (in Unit 1) to where the calcareous bedrock was encountered.

\section{Investigation Activities}

Two $1 \times 2$ meter test units were excavated at 41 BX 291. In addition, eight shovel tests were excavated along the property fence line (Fig. 2). The 


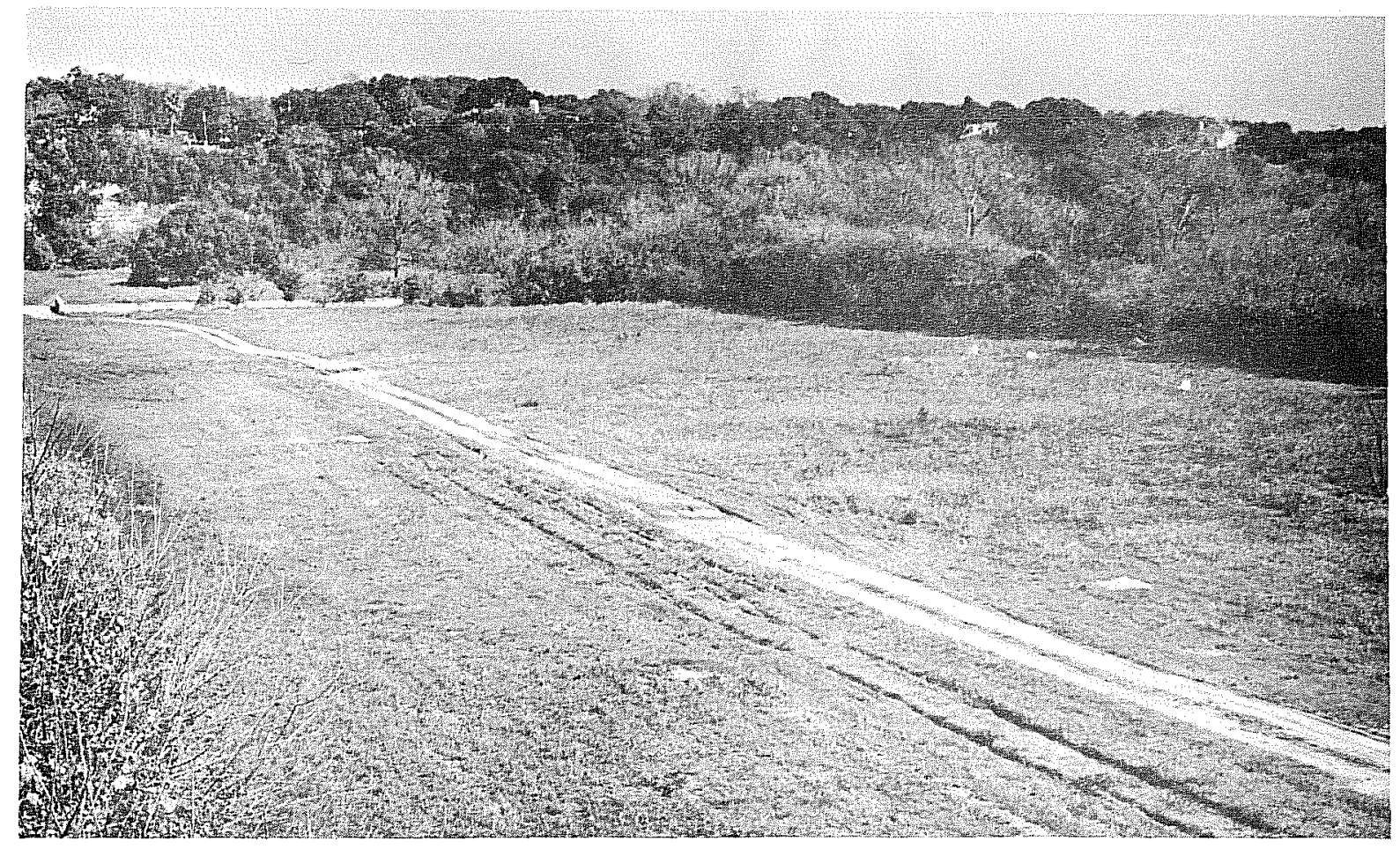

Figure 3. General View of 41 BX 291.
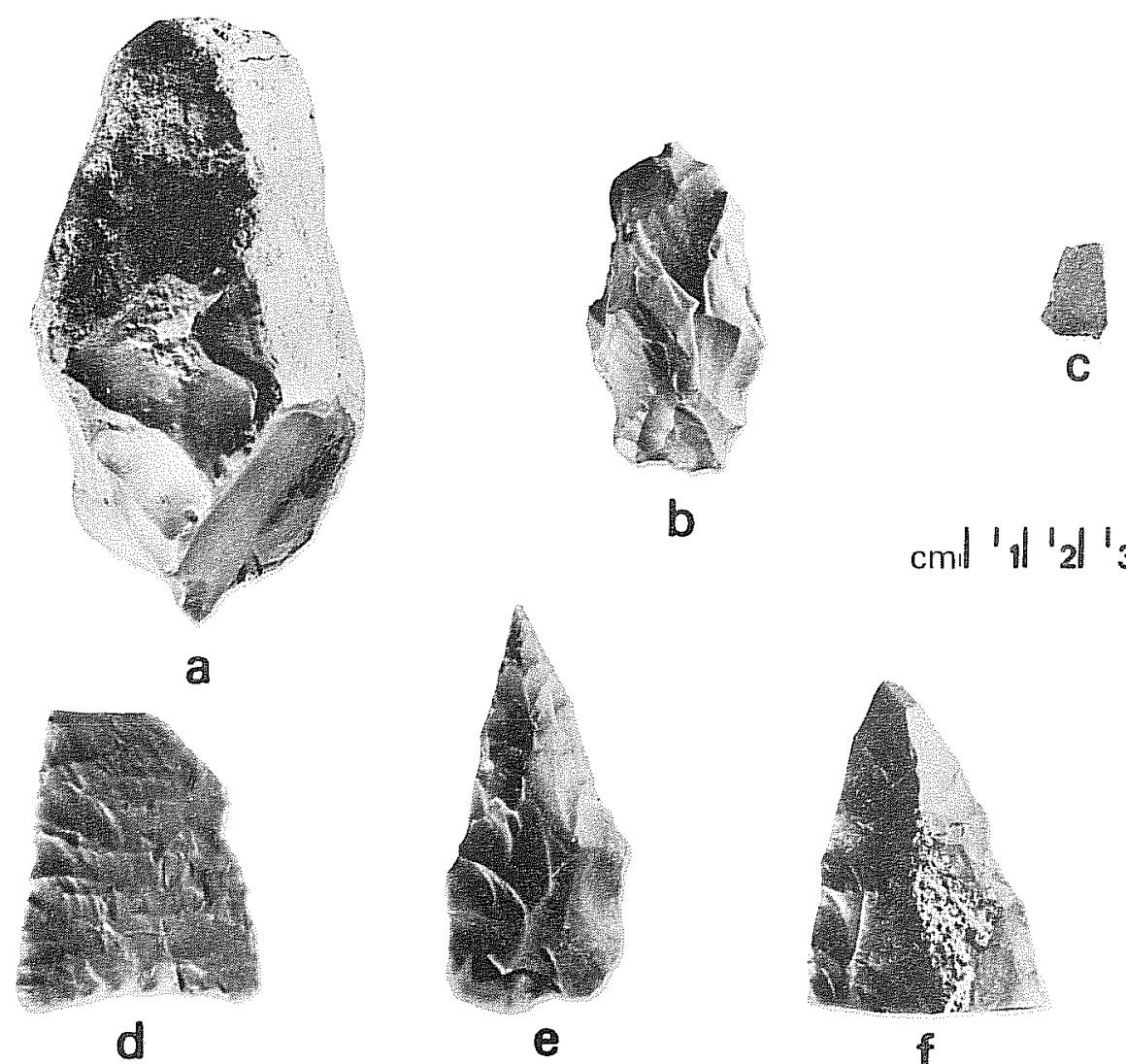

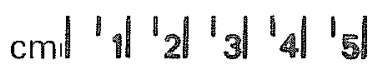
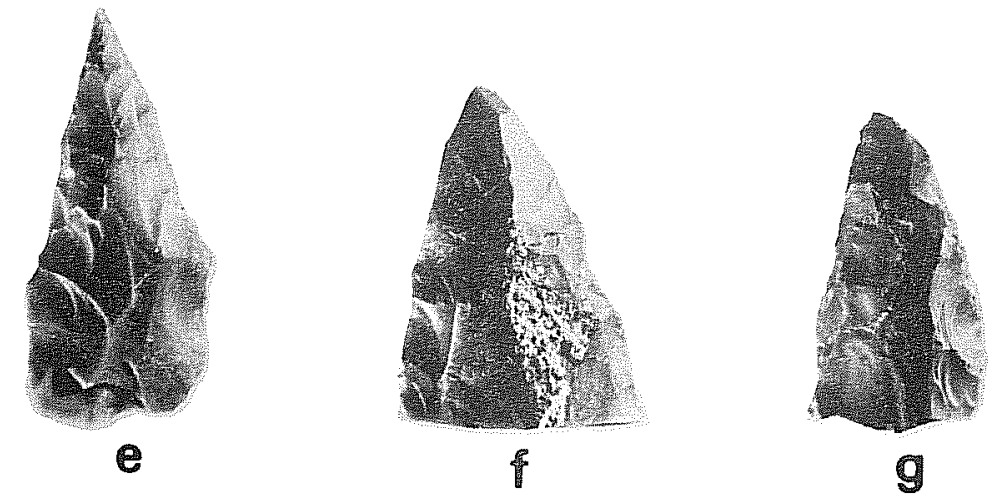

Figure 4. Artifacts from 41 BX 291 and the Shovel Tests. a, Bifacially worked core; $b, d-g$, Bifaces; $c$, Leon Plain potsherd. 
placement of the two test units was biased and designed to yield the maximum amount of information about 41 BX 291 in the short time available for field work. The two units were oriented northwest/southeast on their long axis in order to be at right angles to the fence and dam. The units were dug in arbitrary $10 \mathrm{~cm}$ levels, and all excavated materials were screened through 1/4-inch wire mesh.

Unit 1 was placed as close to the fence as possible and on the highest spot of the site that the thick vegetation would allow. The unit was excavated to a depth of $60 \mathrm{~cm}$ where bedrock was encountered. Figure 5 is a profile of Unit 1 at the property fence line. Cultural material was recovered in all levels of the unit. Historic Anglo-European debris was present in the upper $20 \mathrm{~cm}$ of the unit. The artifacts and their provenience are found in Table 1.

Unit 2 was located at what appeared to be the northernmost extension of the site. This unit was excavated to a depth of $40 \mathrm{~cm}$ where calcareous bedrock was encountered. Figure 5 shows a profile of the unit (oriented northwest/southeast) where the calcareous bedrock is exposed as a slight rise towards the center of the site. Cultural material was recovered in all levels, including historic Anglo-European debris to $20 \mathrm{~cm}$ in depth. The artifacts and their proveniences from this unit are shown in Table 1.

With the exception of ST-C, all other shovel tests (ST-A through ST-H) were excavated along the proposed security fence line to ascertain the width of $41 \mathrm{BX}$ 291 and determine if any other archaeological resources were present along that line (see Fig. 2). ST-C is located to the north of Unit 2. The test holes ranged in size from $35 \times 35 \mathrm{~cm}$ to $50 \times 60 \mathrm{~cm}$. They were all dug in arbitrary $15 \mathrm{~cm}$ levels, and all materials were screened through 1/4-inch wire mesh.

A11 of the shovel tests contained cultural debris; however, ST-A and ST-C are the only two test pits considered to be directly associated with 41 BX 291 due to close proximity. The materials recovered from the other shovel tests can only be indirectly related to $41 \mathrm{BX} 291$ due to the probable disturbances to the area in the past.

Profiles of ST-B, ST-C and ST-F (Fig. 6) best exhibit the soil changes which are attributed to past disturbance in the 01mos Basin. The soil changes in ST-B, ST-C and ST-F are clearly defined. Recent disturbance, in the form of soil mixing, is evident in all of the soil strata with the exception of the "brown clay loam" zone which is homogeneous (see Fig. 6).

Prehistoric and Anglo-European historic cultural materials were recovered from all of the shovel tests. Scattered flakes were the predominant lithic artifact category recovered, along with some Anglo-European historic debris and land snail shells. Unidentifiable animal bone fragments were found in some of the shovel tests. One sherd of Leon Plain pottery (Hester and Hill 1971) was found at the 60-70 cm level in ST-F (Fig. 4,C). It is burnished on both sides and is bone tempered.

Table 2 shows the horizontal and vertical dimensions of the shovel tests and the quantities of the different artifacts recovered from them. None of the material recovered was considered to be in its original context. 


\section{UNIT 2}

EAST WALL PROFILE

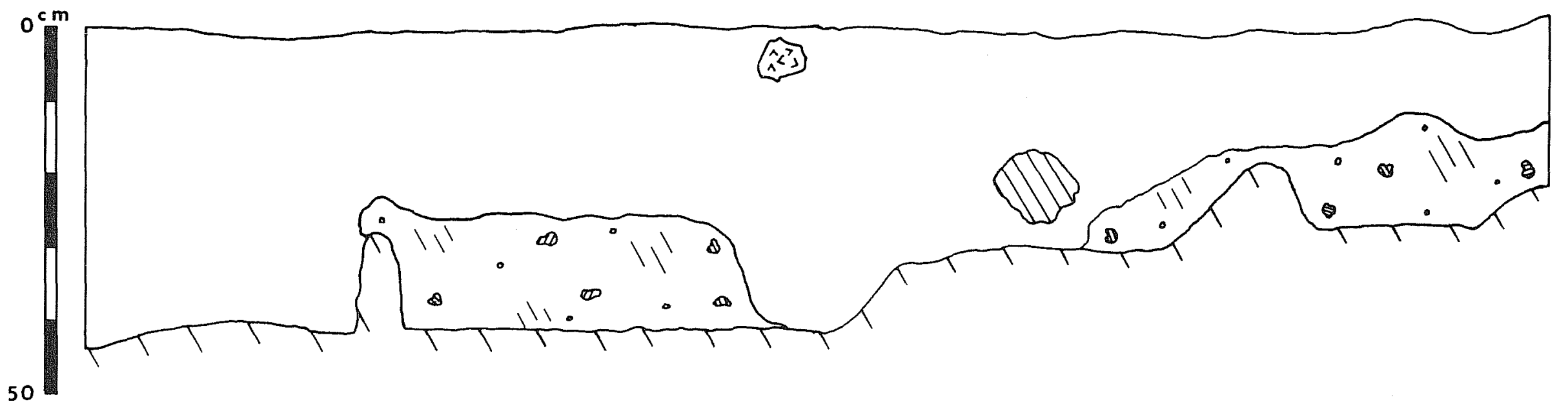

$41 \mathrm{BX} 291$

\section{UNIT 1}

SOUTH WALL PROFILE

\section{局 BURNED ROCK}

CLAY LOAM (brown)

CALCAREOUS and LOAM MIX

@il' CALCAREOUS TRANSITION

MIV CALCAREOUS SOIL/BEDROCK

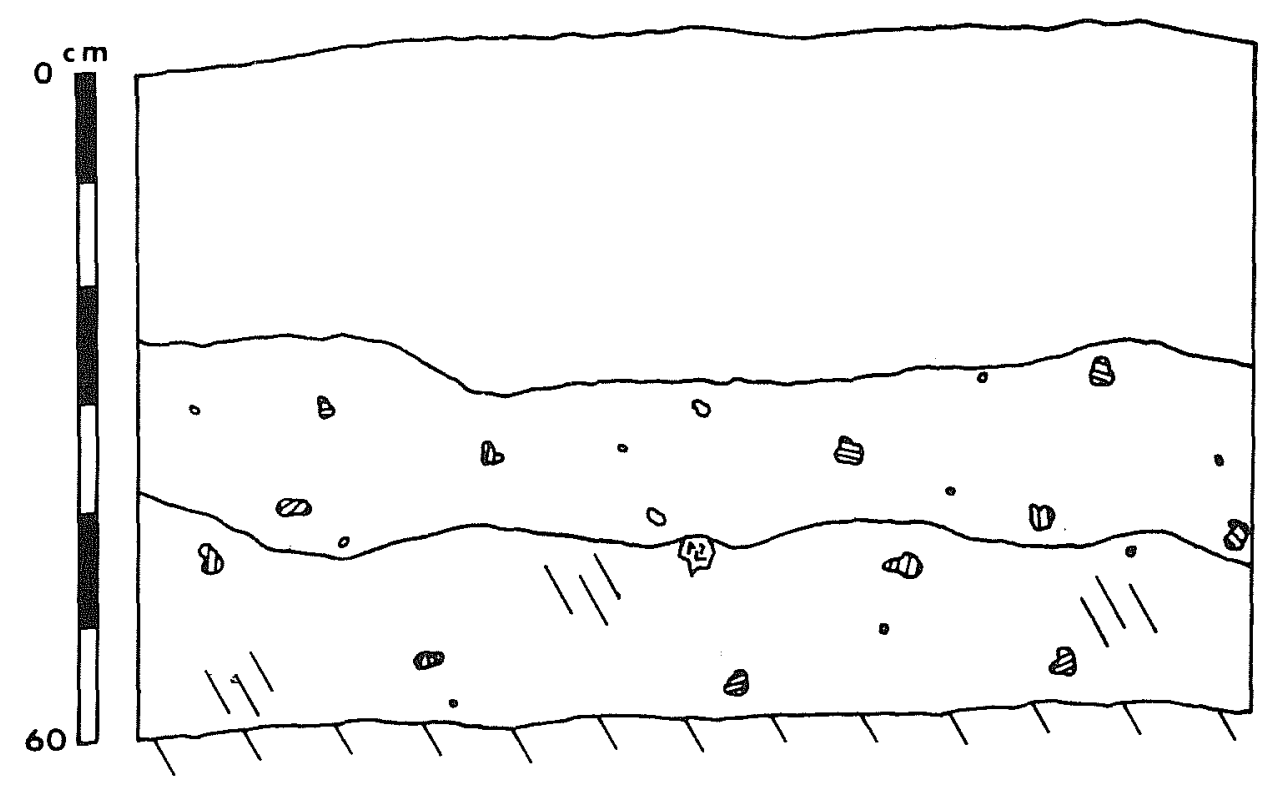

Figure 5. Profiles of units 1 and 2. Soil changes are indicated. 


\section{$41 \mathrm{BX} 291$}

ST - B

SOUTH WALL

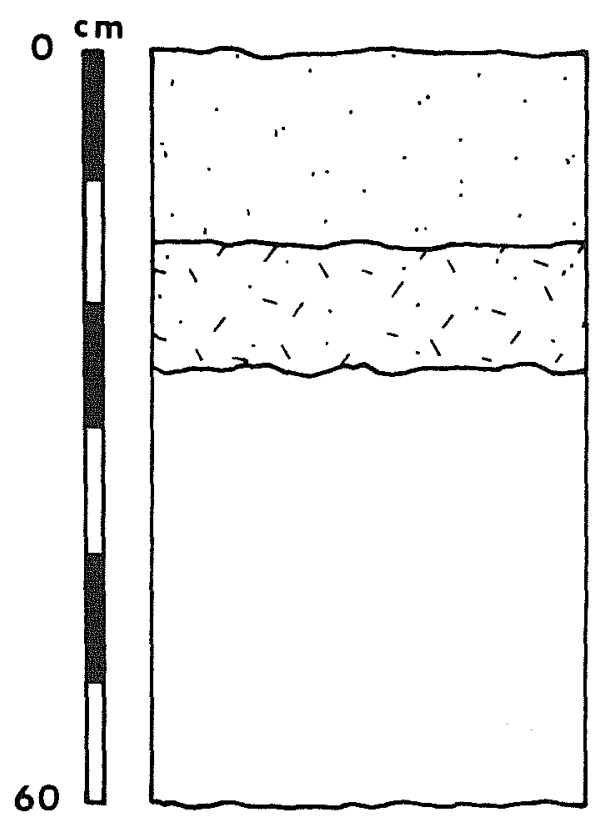

PROFILES

ST. C

SOUTH WALL

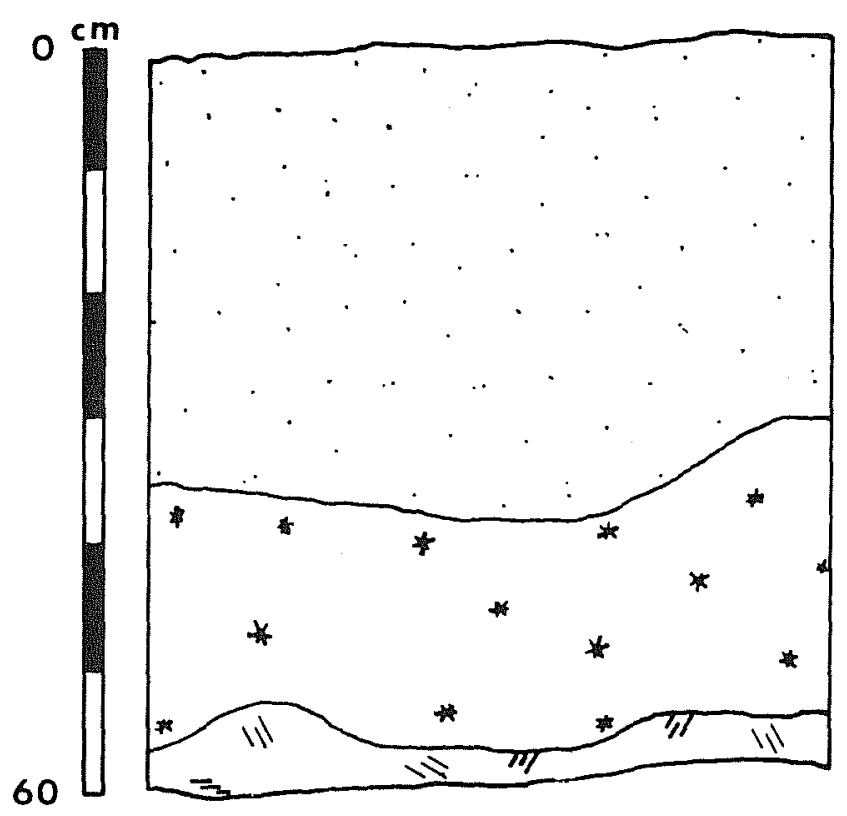

ST- F

NORTH WALL

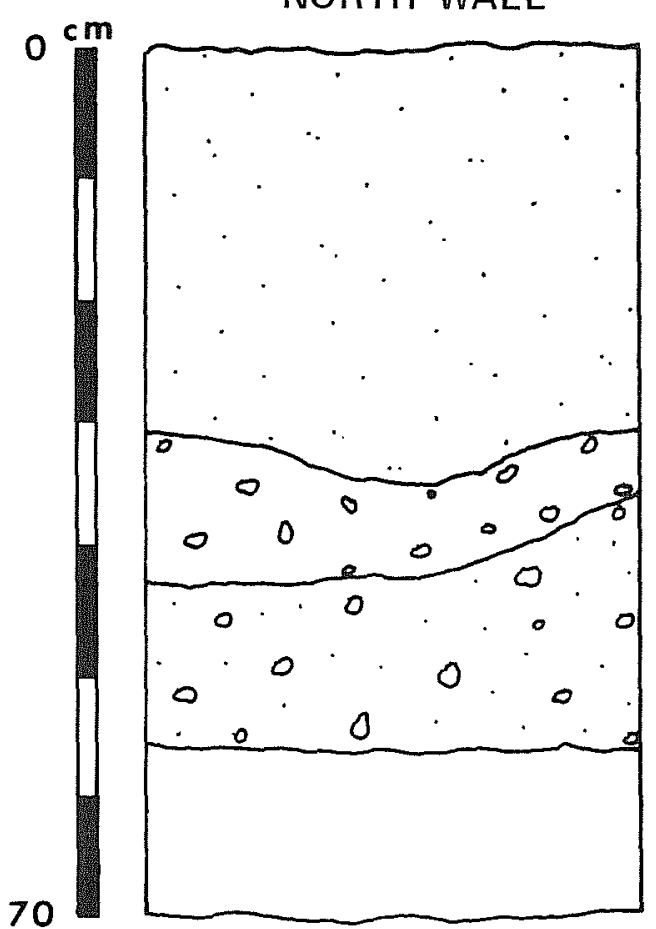

LIGHT BROWN CLAY LOAM (lightly mixed)

00 CLAY GRAVELS (mixed)

CLAY GRAVELS/BROWN CLAY LOAM (mixed)

ORANGE/WHITE/BROWN CLAY LOAM (mixed)
竞 CALCAREOUS SOIL (mixed materials)

** DARK BROWN CLAY LOAM (mixed materials)

BROWN CLAY LOAM 
TABLE 1. ARTIFACTS RECOVERED FROM 41 BX 291 UNITS 1 AND 2

\begin{tabular}{|c|c|c|c|c|c|c|c|c|}
\hline \multirow[b]{2}{*}{$\begin{array}{c}\text { Excavation } \\
\text { Unit }\end{array}$} & \multicolumn{8}{|c|}{$A R T I F A C T S$} \\
\hline & $\begin{array}{l}\text { Bifaces/ } \\
\text { Fragments }\end{array}$ & $\begin{array}{l}\text { Worked } \\
\text { Nodule }\end{array}$ & $\begin{array}{c}\text { Trimmed/ } \\
\text { Utilized } \\
\text { Flakes }\end{array}$ & $\begin{array}{l}\text { Primary } \\
\text { Flakes }\end{array}$ & $\begin{array}{c}\text { Secondary } \\
\text { Flakes }\end{array}$ & $\begin{array}{c}\text { Interior } \\
\text { Flakes }\end{array}$ & $\begin{array}{c}\text { Historic } \\
\text { Items }\end{array}$ & $\begin{array}{c}\text { Bone } \\
\text { Fragments }\end{array}$ \\
\hline \multicolumn{9}{|l|}{ Unit 1} \\
\hline $0-10 \mathrm{~cm}$ & 2 & 1 & & 13 & 47 & 105 & 7 & 1 \\
\hline $10-20$ & 4 & 1 & 7 & 25 & 62 & 187 & 5 & 1 \\
\hline $20-30$ & 1 & & 3 & 38 & 112 & 299 & & \\
\hline $30-40$ & & 1 & 3 & 19 & 53 & 151 & & \\
\hline $40-50$ & & & 1 & 2 & 8 & 19 & & \\
\hline $50-60$ & & & & 4 & 5 & 19 & & \\
\hline Total & 7 & 3 & 14 & 101 & 287 & 780 & 12 & 2 \\
\hline \multicolumn{9}{|l|}{ Unit 2} \\
\hline $0-10 \mathrm{~cm}$ & 3 & 1 & 4 & 16 & 40 & 138 & 4 & \\
\hline $10-20$ & 3 & & 5 & 36 & 90 & 278 & 1 & \\
\hline $20-30$ & & & 1 & 8 & 18 & 64 & & \\
\hline $30-40$ & & & & 12 & 9 & 30 & & \\
\hline Total & 6 & 1 & 10 & 72 & 157 & 510 & 5 & \\
\hline
\end{tabular}


TABLE 2. ARTIFACTS FROM THE SHOVEL TESTS

\begin{tabular}{|c|c|c|c|c|c|c|c|c|}
\hline \multirow[b]{2}{*}{$\begin{array}{l}\text { Shovel } \\
\text { Tests }\end{array}$} & \multicolumn{8}{|c|}{$A R T I F A C T S$} \\
\hline & $\begin{array}{l}\text { Bifaces/ } \\
\text { Fragments }\end{array}$ & $\begin{array}{l}\text { Worked } \\
\text { Nodule }\end{array}$ & $\begin{array}{c}\text { Trimmed/ } \\
\text { Utilized } \\
\text { Flakes }\end{array}$ & $\begin{array}{l}\text { Primary } \\
\text { Flakes }\end{array}$ & $\begin{array}{l}\text { Secondary } \\
\text { Flakes }\end{array}$ & $\begin{array}{l}\text { Interior } \\
\text { Flakes }\end{array}$ & $\begin{array}{l}\text { Historic } \\
\text { Items }\end{array}$ & $\begin{array}{c}\text { Bone } \\
\text { Fragments }\end{array}$ \\
\hline $\begin{array}{c}\text { ST-A } \\
\left(\begin{array}{c}35 \times 35 \\
\times 60 \mathrm{~cm}\end{array}\right)\end{array}$ & & & 1 & 1 & 8 & 19 & 2 & \\
\hline $\begin{array}{c}\text { ST-B } \\
\left(\begin{array}{cc}35 \times 35 \mathrm{~cm} \\
\times 60 \mathrm{~cm})\end{array}\right.\end{array}$ & & & & 1 & 4 & 12 & 2 & \\
\hline $\begin{array}{c}\text { ST-C } \\
(50 \times 60 \mathrm{~cm} \\
\times 60 \mathrm{~cm})\end{array}$ & & 1 & 1 & 3 & 17 & 43 & 1 & \\
\hline $\begin{array}{c}\text { ST-D } \\
(40 \times 40 \mathrm{~cm} \\
\times 60 \mathrm{~cm})\end{array}$ & & & 1 & 2 & 14 & 17 & 1 & 2 \\
\hline $\begin{array}{c}\text { ST-E } \\
(40 \times 40 \mathrm{~cm} \\
\times 70 \mathrm{~cm})\end{array}$ & 1 & & & & 9 & 14 & & 2 \\
\hline $\begin{array}{c}\text { ST-F } \\
(40 \times 40 \mathrm{~cm} \\
\times 70 \mathrm{~cm})\end{array}$ & & $1 *$ & & 3 & 4 & 6 & 3 & 1 \\
\hline $\begin{array}{c}\text { ST-G } \\
(40 \times 40 \mathrm{~cm} \\
\times 60 \mathrm{~cm})\end{array}$ & & & & 4 & 3 & 9 & 2 & \\
\hline $\begin{array}{c}\text { ST-H } \\
(40 \times 40 \mathrm{~cm} \\
\times 55 \mathrm{~cm})\end{array}$ & & & & 1 & 4 & 7 & 1 & \\
\hline TOTAL & 1 & 2 & 3 & 15 & 63 & 127 & 12 & 5 \\
\hline
\end{tabular}




\section{Lithic Artifacts}

A limited analysis of the chert artifacts consisted of sorting into categories to include bifaces and biface fragments; worked nodules (some probably cores); trimmed/utilized flakes; and primary, secondary and interior flakes. Categories for historic items and bone fragments were also included on Tables 1 and 2 to show quantities.

The bifaces and biface fragments category includes any lithics (with one exception) exhibiting the intentional working of both sides of the specimen. One incomplete projectile point was included in this category (see Fig. $4, b, d, e, f$ and $g$ for biface examples).

The worked nodule category is the one exception to the bifaces and biface fragments category. These artifacts are bifacially worked, including four cores and two "tools." The cores are defined as cobbles having one or more flakes removed. Both of the "tools" appear to have been prepared specifically for use (possibiy chopping) but are not further reduced as a core would be. One of the specimens shows battering (Fig. 4,a). It is possible that the two "tools" were test nodules initially struck to test the quality of the chert and were subsequently used as casual tools.

The trimmed and utilized flakes category does not distinguish between edge alteration caused by intentional edge shaping or retouch caused through use. These specimens are found among the primary, secondary and interiar flakes.

The rest of the lithic debitage is divided into primary, secondary and interiar flakes. The primary blakes category includes any chert specimen with $90 \%$ or more dorsal cortex. The secondary flakes include specimens with 1 ess than $90 \%$ cortex. The last category, the interior flakes, includes the rest of the debris with no cortex present on the specimen. All lithic debris was included in the flake categories whether or not a platform and bulb of percussion were present.

None of the recovered chert artifacts is diagnostic for any particular chronological period. One possible exception is a biface (Fig. 4,d) found in the 15-30 cm level of ST-E. The fine workmanship of the specimen is similar to that of some Archaic period artifacts found a few miles away at the St. Mary's Hall site (41 BX 229) on Salado Creek (Dr. Thomas R. Hester, personal communication).

\section{Anglo-European Historic Disturbance}

Historic artifacts (glass, ceramics and metal items) were found in both of the excavation units and all but one (ST-E) of the shovel tests. A category for recent historic items is included in Tables 1 and 2 to show quantities and provenience in relation to the aboriginal artifacts. The presence of historic debris is also included in Table 3 where the land snail shell distributions are discussed.

Recent historic disturbance is represented in $41 \mathrm{BX} 291$ by debris found in the first $20 \mathrm{~cm}$ of both Units 1 and 2 . ST-A had historic materials in its upper $15 \mathrm{~cm}$, and ST-C had one piece of historic material in the 45-60 cm level. A11 of ST-C, which was excavated to $60 \mathrm{~cm}$, appears to be disturbed. This modern disturbance was probably caused by a combination of flooding, plowing and the 01 mos Dam construction activities. 
TABLE 3. LAND SNAIL DISTRIBUTION AT 41 BX 291 AND VICINITY

\begin{tabular}{|c|c|c|c|c|c|c|}
\hline Provenience & Rabdotus sp. & Polygyra sp. & Mesodon sp. & Practicolella sp. & $\begin{array}{l}\text { Rumina } \\
\text { decollata }\end{array}$ & $\begin{array}{c}\text { Anglo-European } \\
\text { Historic } \\
\text { Items } \\
\end{array}$ \\
\hline Unit 1 & A11 Levels & Al1 Levels & All Levels & To $10 \mathrm{~cm}$ & To $40 \mathrm{~cm}$ & To $20 \mathrm{~cm}$ \\
\hline Unit 2 & A11 Levels & Alt Levels & Alt Levels & To $40 \mathrm{~cm}$ & To $30 \mathrm{~cm}$ & To $20 \mathrm{~cm}$ \\
\hline ST-A & Alt Levels & Al1 Levels & All Levels & To $15 \mathrm{~cm}$ & To $30 \mathrm{~cm}$ & To $15 \mathrm{~cm}$ \\
\hline ST-B & To $60 \mathrm{~cm}$ & To $60 \mathrm{~cm}$ & To $60 \mathrm{~cm}$ & & & To $30 \mathrm{~cm}$ \\
\hline$S T-C$ & A11 Levels & To $45 \mathrm{~cm}$ & To $60 \mathrm{~cm}$ & & To $60 \mathrm{~cm}$ & To $45 \mathrm{~cm}$ \\
\hline ST-D & A11 Levels & Al1 Levels & Al1 Levels & To $60 \mathrm{~cm}$ & To $30 \mathrm{~cm}$ & To $30 \mathrm{~cm}$ \\
\hline$S T-E$ & To $70 \mathrm{~cm}$ & Al1 Levels & Al1 Levels & To $70 \mathrm{~cm}$ & To $30 \mathrm{~cm}$ & \\
\hline ST-F & To $70 \mathrm{~cm}$ & To $60 \mathrm{~cm}$ & To $70 \mathrm{~cm}$ & To $45 \mathrm{~cm}$ & To $30 \mathrm{~cm}$ & To $45 \mathrm{~cm}$ \\
\hline$S T-G$ & Al1 Levels & A11 Leve1s & A11 Levels & To $60 \mathrm{~cm}$ & All Levels & To $45 \mathrm{~cm}$ \\
\hline ST-H & To $55 \mathrm{~cm}$ & A11 Levels & A11 Levels & To $45 \mathrm{~cm}$ & To $15 \mathrm{~cm}$ & To $15 \mathrm{~cm}$ \\
\hline
\end{tabular}


Land Snail Remains

A separate distribution chart (Table 3 ) was drawn up to show the different land snail shells found in and around 41 BX 291. Five genera of land snail remains were found in varying quantities during the testing. These are Rabdotus sp., Polygyra sp., Mesodon sp., Practicolella sp. and Rumina decollata. A11 of the snails are native to Texas, with the exception of Rumina decollata which had been introduced from the Mediterranean and is considered to be a garden "pest" (Allen and Cheatum 1961). A representative sample of each snail shell type was collected; therefore, only presence or absence is noted in Table 3.

Since Rumina decollata is a recent species to the area, its presence suggests recent soils or some sort of disturbance such as flooding or plowing. The presence or absence of Anglo-European historic items was also included in Table 3 so as to be seen in conjunction with, and supporting the suggestion of, disturbance in the areas tested.

Rumina decollata was found in the upper layers of the two excavation units as deep as $40 \mathrm{~cm}$. In the shovel tests the species was found as deep as $60 \mathrm{~cm}$.

\section{SUMMARY AND RECOMMENDATIONS}

Testing south of 01 mos Dam was undertaken to determine whether or not the installation of a security fence to protect a Texas State Landmark ( 41 BX 291) would result in any damage to the site. During the course of work, the northern boundary of the site was defined and was found to extend north of the Incarnate Word College property onto the 01mos Dam right-of-way. Shovel tests indicated that no other archaeological resources are present along the rest of the proposed fence line.

Installation of a new security fence is recommended at the proposed location. Part of 41 BX 291 may be slightly damaged by the work; however, the security fence will provide needed protection for the majority of the site. The area that may be affected by the fence installation has previously been subjected to damage from plowing, flooding and dam construction activities.

It is important that $41 \mathrm{BX} 291$, along with other archaeological sites in the 01 mos Basin, be protected. There is a long history represented in the immediate area from Paleo-Indian (Orchard and Campbe11 1954) through European settlement (Brown 1977, Fox 1975), and these resources need to be protected, where possible, from further modern encroachment. 


\section{REFERENCES CITED}

Allen, D. C. and E。 P. Cheatum

1967 Ecological Implications of Fresh Water and Land Gastropods in Texas Archeological Studies. Bulletin of the Texas Archeological Society $31: 291-316$.

Brown, D.

1977 An Archaeological Survey of Proposed Areas for Alternate Roadways at $01 \mathrm{mos}$ Dam, San Antonio, Texas. Center for Archaeological Research, The University of Texas at San Antonio, Archaeological Survey Report 37.

Fox, A. A.

1975 An Archaeological Assessment of the Southern Portion of the $01 \mathrm{mos}$ Basin, Bexar County, Texas. Center for Archaeological Research, The University of Texas at San Antonio, Archaeological Survey Report 9.

Hester, T. R. and T. C. Hill, Jr.

1971 An Initial Study of a Prehistoric Ceramic Tradition in Southern Texas. Plains Anthropologist 16(53):195-203.

Orchard, C. D. and T. N. Campbe 11

1954 Evidence of Early Man from the Vicinity of San Antonio, Texas. Texas Journal of Science 6(4):454-465.

Taylor, F. B., R. B. Hailey and D. L. Richmond

1966 Soil Survey of Bexar County, Texas. U. S. Department of Agriculture, Soil Conservation Service, Series 1962, 12. 